\title{
Wielofazowy proces instytucjonalizacji regionu
}

\begin{abstract}
The aim of the article is to characterized the theory of institutionalization of the region. Its author, Finnish geographer Anssi Paasi, described region as an effect of multiphase process that takes shape of an institutionalization. Such process starts when region has its territorial frame (territorial phase), then symbolic images are created and located in people's consciousness inside and outside of the region (symbolic phase). In the next phase (called an institutional) symbolic images are transformed into formal institutions (law, strategies, organizations). In that phase regional actors operate in the field of a regional discourse.

Region is a socio-spatial phenomenon, a place where symbolic and institutional acting between different regional actors takes place. It is a constant process of legitimization specific images of regions, which is used to create a brand of the region and structuring the regional identity of people living in the region. The moment a regional identity and a regional brand is created by regional institutions is defined as a full phase of institutionalisation. Paasi's theory is an important and interesting proposal, which can enrich the sociological surveys of the region, but it is necessary to supplement it. The process of institutionalization of the region involves all regional actors, Paasi argues that only formal organizations. Additionally, this process is dependent on the internal and external context and on the
\end{abstract}

1 Jacek Poniedziałek, Wydział Nauk Społecznych, Uniwersytet Warmińsko-Mazurski w Olsztynie, Polska, jacek.poniedzialek@wp.pl. 
history of the region. These complements enriches heuristic value of the theory characterised in the article.

\section{Key words:}

region, regional identity, theory of institutionalisation, sociology of region, Ansii Paasi

\section{WPROWADZENIE}

Analiza dostępnej, poświęconej regionowi jako zjawisku społecznemu literatury socjologicznej pozwala stwierdzić, że pomimo różnic większość proponowanych definicji wskazuje na występowanie trzech konstytuujących go elementów. Są to: przestrzeń, zbiorowość, z jej specyfiką społeczno-kulturową oraz ustalone dla tej przestrzeni i zbiorowości stosunki władzy (Miazga, 2010, s. 11). Część badaczy poprzestaje na wyliczeniu strukturalnych elementów wchodzących w skład regionu, rzadziej wskazuje się na relacje i procesy strukturalne zachodzące w jego wnętrzu. Dominacji statycznych i strukturalnych podejść do regionu należy przeciwstawić perspektywę procesualną, która ukaże region jako dynamiczną i realną jednostkę społeczną ,i przestrzenną lub terytorialną, złożoną z różnych elementów powiązanych ze sobą” (Chojnicki, 1996, s. 11). W tej społeczno-przestrzennej konfiguracji struktur i zjawisk zachodzą złożone relacje pomiędzy poszczególnymi elementami struktur, przynosząc skutek w postaci pojawiania się specyficznych, budujących region zjawisk (Chądzyński, Nowakowska, Przygodzki, 2007, s. 40). Zdaje się, że perspektywą teoretyczną, która najpełniej opisuje wymiar strukturalny istnienia regionu oraz jego specyficzny, procesualny typ wewnętrznych powiązań, jest koncepcja instytucjonalizacji regionu autorstwa fińskiego badacza Anssi Paasiego. W ramach tego podejścia, jak stwierdza nie bez racji Frans Schrijver, uwaga przeniesiona została z poziomu statycznych analiz strukturalnych na poziom refleksji o relacjach pomiędzy elementami struktur regionu, które to przybierają charakter procesu instytucjonalizacji (Schrijver, 2006, s. 22). Zastosowanie w badaniach teorii instytucjonalizacji regionu pomaga wyjaśnić nie tylko samo jego istnienie, ale jest niezwykle pomocne wówczas, gdy chce się pojąć to, w jaki sposób regiony się tworzą, przekształcają, trwają lub znikają. Prezentowany tu artykuł ma na celu scharakteryzowanie tej koncepcji poprzez opis samego procesu instytucjonalizacji regionu wraz z charakterystyką występujących w nim faz oraz typów aktorów społecznych biorących w nim udział. Następnie w celu przezwyciężenia słabości prezentowanej tu koncepcji wprowadzonych zostanie kilka korekt mających 
uzupełnić jej braki elementami socjologicznej teorii podmiotowości i osadzenie procesu instytucjonalizacji w kontekście kulturowym i historycznym, w jakich regiony funkcjonują.

\section{INSTYTUCJONALIZACJA REGIONU}

Teoria instytucjonalizacji regionu wzoruje się na koncepcji pola i habitusu Pierra Bourdieu, dla którego termin region wywodzi się od „magicznego, a przez to fundamentalnie społecznego aktu diacrisis [to pojęcie - przyp. J.P.], wprowadza podział, granicę, nieciągłość w dotychczasową naturalnq ciągłość przestrzeni” (Bourdieu, 1991, s. 221). Moment powołania do istnienia regionu jest zdaniem francuskiego socjologa swoistym „aktem magii społecznej, który może stworzyć różnicę ex nihilo, lub też (jak to częściej bywa) eksploatując, by tak rzec, różnicę już wcześniej istniejące” (Bourdieu, 1991, s. 119). Bourdieu wyjaśnia, że ów magiczny akt powołania do istnienia regionu polega na potwierdzeniu autorytetem, który ma moc ładotwórczą i przez to jest źródłem prawdy, jego istnienia. Jest on w zasadzie aktem poznawczym „opartym, podobnie jak wszelka symboliczna władza, na rozpoznaniu i uznaniu [...], powołującym do istnienia to, czego istnienie władza potwierdza [...], jest potencjałem tworzenia zarezerwowanym dla auctora [...]. Regionalizacja przestrzeni jest więc aktem władzy, który powołuje do istnienia, definiuje i autoryzuje granice, przepowiada, sankcjonuje i naturalizuje różnice, nominuje i deleguje reprezentującą je grupę” (Bourdieu, 1991, s. 222). Moc sprawcza owej magii społecznej, która poprzez akt nazwania powołuje do życia fundament regionu, uzależniona jest w ostatecznej instancji od jednostki lub znacznie częściej społecznej instytucji, która tego aktu dokonuje, manipulując dostępnymi sobie zasobami materialnymi i symbolicznymi.

Zdaniem zainspirowanego strukturalnym konstruktywizmem Anssi Paasiego region jest dynamiczną konstrukcją podlegającą zmianom. Kształtowanie się regionu jest procesem rozciągniętym pomiędzy przeszłością, teraźniejszością i projektowaną przez regionalne jednostki i instytucje w oparciu o przeszłość przyszłością. Paasi stwierdza, że instytucjonalizacja regionu jest „społeczno-przestrzennym procesem w efekcie którego, pewne jednostki terytorialne pojawiają się jako elementy zbiorowości, kształtują się i przejawiają w różnych sferach społecznych działań i zbiorowych tożsamości” (Paasi, 1986, s. 121). W koncepcji fińskiego badacza regiony nie są pasywnym przedmiotem czy instrumentem działania społecznego ani funkcjonującym ponadindywidualnie bytem istniejącym ponad sferą ludzkich działań zupełnie niezależnie. Są one, jak zauważa Andrzej Bukowski, „częścią tych działań, która ujawnia się właśnie poprzez praktyki, 
oczekiwania lub intencje aktorów społecznych” (Bukowski, 2011, s. 52). W tym rozumieniu konstruowanie regionów to element sekwencji praktyk mających na celu społeczne zorganizowanie przestrzeni. Proces ów zachodzi w różnych skalach czasowych i na różnych poziomach regionalnych struktur społecznych, gospodarczych i politycznych oraz w różnych typach społecznych grup regionalnych aktorów (Paasi, 2001, s. 16). Proces nie jest ograniczony do zorganizowanej zbiorowości terytorialnej zamieszkującej przestrzeń jakiejś szczególnej wielkości czy do nowych regionów pojawiających się jako rezultat wspomnianego procesu w nieodległej przeszłości, ale również odnosi się do powstawania, rozwoju i ewentualnego zanikania regionów tradycyjnych.

W teorii instytucjonalizacji zakłada się, że regiony nie są po prostu historycznie czy naturalnie daną jednostką terytorialną będącą ramą funkcjonowania jakiejś mniej lub bardziej zorganizowanej zbiorowości społecznej, regiony są „społecznymi, politycznymi i ekonomicznymi konstruktami [...], które mogą być słabo obecne w życiu codziennym zwykłych ludzi, [...] są one reprezentacjami publicznymi, które dosłownie zajmują miejsce w sferze [...] dyskursów” (Paasi, 1999, s. 217). Region nie jest tylko korelatem zbiorowości regionalnej spajanej wspólną tożsamością (takie rozumienie jest rozpowszechnione w polskiej socjologii regionu), nie jest również tylko i wyłącznie zbiorowością opisaną w konwencji, jaką zaproponował Benedict Anderson, czyli wspólnota wyobrażonq (Anderson, 1997). Jest raczej przestrzenią zależności, przestrzenną konstelacją, w obrębie której „działa władza, złożona z obrazów, dyskursów, strategii oraz innych praktyk społecznych, politycznych, ekonomicznych, administracyjnych i kulturowych, które przeniknięte są stosunkami władzy” (Paasi, 1990, s. 243-244).

W myśl opisywanej tu teorii region jest konstruktem podlegającym procesowi wielofazowej instytucjonalizacji, to ciąg wzajemnie powiązanych zmian. Instytucjonalizacja regionu to proces społeczno-przestrzenny, w wyniku którego określona jednostka terytorialna wyłania się jako „część przestrzennej struktury danego społeczeństwa, zostaje uznana i obdarzona tożsamością w różnych sferach działań społecznych i społecznej świadomości [...]. Proces ten jest wyrazem założeń poczynionych przez lokalnych lub nielokalnych aktorów oraz decyzji przez nich podjętych. Po zakończeniu procesu instytucjonalizacji region podlega nieustannej reprodukcji na gruncie rozmaitych praktyk społecznych, to znaczy w sferach ekonomii, polityki, prawodawstwa, administracji, kultury itd. Rodowód tych praktyk niekoniecznie związany jest z tą konkretną jednostką przestrzenną [...], zazwyczaj [ulokowany jest - przyp. J.P.] na poziomie międzynarodowym lub państwowym. W trakcie instytucjonalizacji region uzyskuje określoną tożsamość, 
której nie da się sprowadzić do poziomu świadomości ludzi tam mieszkających” (Paasi, 1990, s. 243-244).

Jak wspominałem wyżej, scharakteryzowany proces to zdaniem Paasiego instytucjonalizacja regionu. Wyróżnić w nim można analitycznie cztery elementy, mające charakter „nadania terytorialnego, symbolicznego i instytucjonalnego kształtu regionowi oraz osadzenia go w strukturze i świadomości określonej społeczności terytorialnej” (Bukowski, 2011, s. 52). Wyróżnione elementy procesu mają charakter poszczególnych etapów ciągu powiązanych ze sobą zmian społecznych formujących większy układ lub też subprocesów mogących zachodzić w odosobnieniu, ale układających się poprzez wzajemną współdeterminację w swoistą całość, region o dynamicznym, procesualnym charakterze (Schrijver, 2006, s. 61).

\section{FAZA TERYTORIALNA}

Pierwsza z nich nosi nazwę fazy terytorialnej, albowiem to właśnie wtedy zarysowują się i rozwijają terytorialne ramy regionu (Poniedziałek, 2011, s. 35). Obejmuje między innymi procesy lokalizacji kluczowych społecznych praktyk, takich jak: gospodarka, polityka czy administracja, które stanowią oparcie dla transformacji regionalnej, określając zarazem granice regionu (Poniedziałek, 2010, s. 22-27). Faza terytorialna instytucjonalizowania się regionu odnosi się, jak wspominałem, do ustanowienia regionalnych granic, nie tylko formalnych, ale również przestrzennych ograniczeń społecznych praktyk oraz identyfikacji tych ograniczonych przestrzennie praktyk jako odrębnej społecznie przestrzennej jednostki. Jak celnie zauważa Schrijver, kluczowym elementem tej fazy jest uświadomienie sobie swoistości tych ograniczonych przestrzennie społecznych praktyk zlokalizowanych w konkretnym terytorium, a także ich swoistości i odrębności zarówno „wewnątrz, jak i na zewnątrz regionu” (Schrijver, 2006, s. 61).

Faza terytorialna - mająca charakter wyznaczania granic na określonym terytorium społecznym praktykom oraz odnosząca się do lokalizowania na tym terytorium nieformalnych i formalnych społecznych, politycznych i gospodarczych instytucji - stanowi bazę dla kolejnych faz procesu instytucjonalizowania się regionu. Stanowi kluczowy element formowania się tożsamości regionalnej rozpowszechnionej wśród zamieszkującej jakąś przestrzeń zbiorowości. To punkt odniesienia w procesach formowania się zbioru regionalnych wyobrażeń i symboli, formalnych i nieformalnych norm i instytucji społecznych. Wskazane wyróżniki regionu są nieustanie poddawane społecznej krytyce i rewizji, zarówno wewnątrz 
regionu, jak i od zewnątrz. Związane jest to w sposób nierozerwalny z procesami określania przestrzeni, terytorium regionu poprzez zarysowanie formalnych, a przede wszystkim społeczno-kulturowych jego granic. Wyznaczanie granic to proces niemający w zasadzie końca, podejmowany przez aktorów regionalnych zarówno w fazie terytorialnej, symbolicznej, jak i instytucjonalnej.

Zdaniem Paasiego obraz świata składającego się z przylegających i oddzielonych od siebie granicami przestrzennymi, specyficznych kulturowo zbiorowości rysowany przez tradycyjną humanistykę nie przystaje do współczesności (Paasi, 2002, s. 807). Definiowanie regionów jako swoistych terytorialnych pojemników (territorial containers) o jasno i wyraźnie, często formalnie zarysowanych granicach politycznych i społeczno-kulturowych jest błędne, albowiem takie regiony współcześnie po prostu nie występują. Perspektywa ujmowania regionów w krytykowany w tym podejściu sposób bierze się stąd, że znaczna część badaczy interesujących się problematyką regionów skłania się do opisu zjawisk charakterystycznych dla globalizującego się świata, w szczególności zaś jednoczącego się w strukturach Unii Europejskiej znacznego fragmentu kontynentu europejskiego, z perspektywy wewnątrzregionalnej albo opisując to, co się dzieje pomiędzy nimi, „zamiast ujmować regiony jako część tych procesów. Do tego dochodzi automatyczne niemal ujmowanie regionu jako poziomu pośredniego pomiędzy państwem a społecznościami lokalnymi, charakterystyczne dla podejść zajmujących się kwestiami zarządzania i terytorialności. Poza tym wielu badaczy traktuje słowa region i miejsce jako synonimy, używając skal opartych na takich kategoriach (np. lokalne/ponadlokalne), lub samych tych kategorii do charakterystyki specyficznego doświadczania przestrzeni” (Bukowski, 2011, s. 51).

Terytorium regionu będzie więc przestrzennym korelatem społeczno-kulturowych praktyk budowania granic w postaci wyróżniających się norm, wartości, instytucji formalnych i nieformalnych, strategii i kodów symbolicznych, przejawiających się na poziomie publicznych dyskursów, które zakorzeniają się w tożsamości regionalnej mieszkańców regionu. Terytorium regionu powinno być zatem ujmowane nie jako stateczna przestrzennie lokalizacja życia społecznego jakiejś zbiorowości, ale jako wiązka procesów budowania regionalnych dystynkcji odnoszonych do jakiegoś terytorium traktowanego jako swoiście regionalne. Zarys granic terytorium regionu jest stale kontestowany z zewnątrz i wewnątrz regionu, dlatego w zasadzie nie ustają próby ich utwierdzania w świadomości ludzkiej, w nieformalnych i sformalizowanych społecznych praktykach. Granice współczesnych regionów są płynne i porowate. Poprzez zagnieżdżanie się regionu zarówno w rzeczywistości lokalnej, jak i ogólnopaństwowej czy ogólnonarodowej, a także w efekcie przejmowania przez regiony wielu prerogatyw dawniej zare- 
zerwowanych dla państw można ująć region jako wiązkę procesów toczących się równolegle z rzeczywistością lokalną i państwową, ale nie stanowiących szczebla zjawisk pomiędzy nimi pośredniego.

\section{FAZA SYMBOLICZNA}

Faza symboliczna instytucjonalizowania się regionu, w porządku analitycznym druga w kolejności, w rzeczywistości przebiega równolegle z fazą terytorialną charakteryzowanego tu procesu. Wówczas to dochodzi do „produkcji i reprodukcji symbolicznego znaczenia regionu, treści identyfikacji regionalnej poprzez użycie symboli odnoszących się do terytorium regionu” (Schrijver, 2006, s. 61). W opisywanej tu fazie zarysowuje się i rozwija symboliczna postać regionu, dochodzi do przekładania wymiaru terytorialnego i społecznego regionu (w rozumieniu występowania na terytorium regionu jakiejś zbiorowości) na język mitu. Jest ona kluczowa dla możliwości społecznej i politycznej mobilizacji mieszkańców. Jej ważność podkreśla fakt, że w czasie jej trwania tworzy się określona wizja społecznego ładu zakodowana w nazwach, symbolach, ikonografii i „narracjach mitotwórczych, których celem jest wykreowanie imago regionis” (Gąsior-Niemiec, 2004, s. 28).

Ten etap formowania się regionu dotyczy przede wszystkim użycia języka i jego treści, kluczowych dla dyskursywnej formy tworzenia symbolicznego wymiaru kształtowania się regionu. Język jest bowiem podstawowym narzędziem konstruowania rzeczywistości społecznej, stanowi budulec znaków, symboli i wyobrażeń ludzkich. Jego znajomość pozwala również na odczytanie znaczeń, które niosą z sobą produkty użycia języka, czyli w tym przypadku odniesione do jakiegoś terytorium symbole, znaki i opowieści. W tej fazie przybierają one kształt dyskursywny, stając się mniej lub bardziej całościową formą symbolicznego przejawiania się regionu. Pomimo relatywnej trwałości symboliczne przejawy instytucjonalizowania się regionu nie powinny być traktowane jako odwieczne i niezmienne. Wręcz przeciwnie, wpisując się w dynamiczny charakter procesów instytucjonalizacyjnych, są stale reprodukowane w regionalnych praktykach dyskursywnych, ponadto ich treść, forma i znaczenie często ulegają zmianie. Dopasowywane są przez zbiorowość regionalną bądź kluczowych aktorów regionalnych do warunków, w jakich może instytucjonalizować się region. W ten sposób teoria instytucjonalizacji regionu odchodzi zupełnie od klasycznych koncepcji, w których region to również regionalny zasób niezmiennych wartości kulturowych, materialnych i niematerialnych, transmitowanych międzypokoleniowo w procesach socjalizacji. 
Układające się w większe całości dyskursywne mity i symbole regionalne na zewnątrz regionu budują jego obraz jako pewnej całości, pomagają poprzez tę dystynkcję regionowi wyróżnić spośród innych tego rodzaju tworów społeczno-przestrzennych. Z drugiej strony ich upowszechnienie i internalizacja powodują, że stają się one integralną częścią tożsamości społecznych jednostek zamieszkujących region. Powstałe w wyniku tego kolektywne reprezentacje będą pełnić funkcję integrującą w zbiorowości regionalnej. Wówczas to bowiem dochodzi do przełożenia obiektywnych cech topograficznych na afektywnie postrzegane cechy krajobrazu, historii na tradycję, rytuałów na procedury, uruchomiony zostaje proceder mitografii lub wynajdowania tradycji.

Symboliczne tworzenie i konsumpcja przestrzeni uzależnione są od posiadania dużych zasobów kapitału, w szczególności kapitału kulturowego, to zaś z reguły charakteryzuje przede wszystkim regionalne elity (artyści, politycy, przedsiębiorcy, naukowcy itp.) i mass media. Tak więc kluczowych aktorów regionalnych traktować należy jako „aktorów skupiających w strategiach i układach regionalnych z jednej strony instytucjonalnie określone szanse i możliwości [...], z drugiej kulturowo dostępne symbole i narracje” (Bukowski, 2006, s. 81). Aktorzy ci skupiają swe działania w nieformalnych bądź sformalizowanych instytucjach zlokalizowanych w regionie, wykorzystują symboliczne zasoby regionu do działań zmierzających do kształtowania tożsamości regionalnej mieszkańców z wykorzystaniem narzędzi przemocy symbolicznej. Używają również tych zasobów do utwierdzania odbioru regionalnego wizerunku o konkretnym wydźwięku na zewnątrz. Dodatkowo posiłkują się nimi przy nadawaniu kierunku procesom regionalnego rozwoju społecznego i gospodarczego, używając ich jako treści w rozmaitych strategiach. Choć przyznać należy, że udział w tym procesie mogą mieć również zwykli mieszkańcy regionu, niemniej jednak z reguły mają oni mniejsze możliwości wpływania na jego kierunek i treści w nim zawarte.

Wynikająca z formowania się symbolicznego wymiaru regionu dialektyka skutkuje wywołaniem działań społecznych odnoszących się do regionu, które „osadzone są w dwóch przenikających się kontekstach: odgórnym, w formie procesów kontroli i zarządzania, oraz oddolnym, w postaci terytorialnej identyfikacji” (Bukowski, 2011, s. 53). Rezultatem tego jest ponadlokalne rozciągnięcie społecznej przestrzeni otaczającej jednostkę oraz powstanie ponadlokalnej sfery publicznej budowanej przez dyskurs czerpiący treści z regionalnego zasobu symbolicznego, formujący regionalne instytucje i tożsamości mieszkańców. Wszystko to zaś, jak przekonuje Paasi, rodzi instytucjonalne i społeczne dążenia, które w praktyce nierzadko przekształcają się w zorganizowane i powtarzalne w czasie społeczne praktyki konstruowania regionu (Paasi, 2003, s. 477). 


\section{FAZA INSTYTUCJONALNA}

Ściśle powiązana z terytorialnym, a w szczególności symbolicznym wymiarem formowanie się regionu, jest wyszczególniona przez Paasiego faza trzecia, zwana instytucjonalną. Wówczas to mamy do czynienia z „pojawianiem się regionalnych instytucji utrzymujących i upowszechniających obraz regionu, instytucji i organizacji które zajmują się komunikowaniem treści wchodzących w skład tożsamości terytorialnej” (Schrijver, 2006, s. 61). W ten sposób fiński badacz odwołuje się do socjologicznego nowego instytucjonalizmu oraz prac takich autorów jak John Mayer czy Victor Nee, oraz perspektywy neoinstytucjonalnej w ekonomii (Kania-Jasińska, 2006, s. 550-551). Nawiązując pośrednio do koncepcji historyka gospodarki Douglassa C. Northa, można stwierdzić, że w charakteryzowanej tu teorii instytucje to ograniczające ludzkie zachowania strukturyzacje interakcji społecznych, gospodarczych i politycznych. Mają one dwojakiego rodzaju charakter, z jednej strony są to nieformalne wierzenia, tabu, wyobrażenia, tradycje, mity, zwyczajowe formy zachowań, z drugiej przybierają formę znormalizowanych reguł, takich jak np. normy prawne, konstytucje, umowy czy strategie. Instytucje ewoluują stopniowo, „łącząc przeszłość z teraźniejszością i przyszłością. Historia w konsekwencji jest w dużej mierze opowieścią o ewolucji instytucjonalnej” (North, 1991, s. 97). Również regiony jako instytucje odniesione do jakiejś zbiorowości i terytorium, budowane dzięki regionalnej mitografii, choć nie tylko, mają procesualną i zmienną naturę. Na uformowanych przez dwie poprzednie fazy fundamentach regionu nadbudowywane są instytucje regionalne w postaci nieformalnych reguł i norm postępowania, z drugiej strony w postać regionalnych norm prawych i formalnych przepisów, które stanowią instrumentarium funkcjonowania sformalizowanych organizacji regionalnych. Jednym z podstawowych tworzyw, zarówno instytucji nieformalnych, jak i sformalizowanych, jest wypracowana w fazie symbolicznej regionalna mitografia.

Wówczas to tworzone są bądź jeśli istnieją ulegają znacznemu wzmocnieniu „regionalne formacje polityczne, zawodowe, stowarzyszenia pozarządowe, biznesowe, międzygminne, powstaje i rozpowszechnia się regionalna prasa, radio i inne mass media” (Poniedziałek, 2011, s. 36). Istotne jest w szczególności wytworzenie się instytucji mających z mocy prawa możliwości konstruowania czy implementacji i stosowania sformalizowanych norm prawnych odnoszących się do terytorium regionu i zamieszkującej go zbiorowości (np. prawodawstwo regionalne czy strategie i programy rozwoju społecznego, kulturalnego czy gospodarczego regionu). W przypadku instytucji sformalizowanych drugim istotnym źródłem ich treści są źródła zewnętrzne w postaci ogólnopaństwowego czy ponadpaństwowego 
(w przypadku przynależności do bloków państw, np. UE) porządku prawnego czy wartości i norm kultury narodowej dominującej w danym państwie. Chodzi tu o obdarzone odpowiednimi kompetencjami instytucje regionalnego władztwa politycznego (Tomaszewski, 2007, s. 11).

Zdaniem Paasiego obdarzone stosownymi kompetencjami formalne organizacje regionalne (np. administracja regionu, jego władze i organizacje od niej zależne lub powiązane) nadają procesom instytucjonalizacji regionu dynamiki, wzmacniając poprzez swoje funkcjonowanie i jego efekty istnienie regionu jako społeczno-przestrzennej kategorii przejawiającej się w sferze „działań społecznych i społecznej świadomości” (Paasi, 1986, s. 121). Efektami działań są rzecz jasna nie tylko formalne przepisy prawa, przykładowo w postaci strategii rozwojowych i innych dokumentów planistycznych, ale również modyfikowane treści (bądź tworzone na nowo) regionalnej mitografii, strukturyzowanie interakcji wewnątrzregionalnych przez egzekwowanie stosowania prawa. Tworzenie się formalnych organizacji regionalnego władztwa, w postaci chociażby regionalnej administracji, prowadzi do kreowania i upowszechniania regionalnej mitografii, symboliki regionów budującej jego obraz w świadomości mieszkańców regionu oraz w świadomości przedstawicieli środowisk wobec niego zewnętrznych.

Powstawanie i funkcjonowanie regionalnej administracji oznacza zatem zwiększenie się możliwości tworzenie i reprodukowania regionu w sferze wyobrażeń i symboli oraz tworzącego je języka. Działania te mogą mieć charakter zwykłego adaptowania istniejących wyobrażeń i symboli, tak by mogły być dopasowane do ram, jakie stanowią formalne instytucje funkcjonujące w regionie. Może również dochodzić do tworzenia zupełnie nowych wyobrażeń i symboli regionu, których źródłem, kodyfikatorem i interpretatorem będą organizacje regionalnej administracji. Tworzenie się sieci regionalnych organizacji administracyjnych prowadzić może do „pojawiania się innych typów organizacji, albo w wyniku działalności celowej poprzez subsydiowanie ich funkcjonowania, albo jako niezamierzony skutek działań w sferze medialnej, edukacyjnej czy w ramach społeczeństwa obywatelskiego. To może z kolei być źródłem tworzenia się i wykorzystywania symboli regionalnych i potwierdzania kształtu terytorialnego regionu” (Schrijver, 2006, s. 62).

W trzeciej fazie dochodzi do powstania i rozprzestrzenienie się instytucji, których zadaniem będzie stabilizacja, wzmocnienie oraz reprodukcja terytorialnego i symbolicznego kształtu regionu przez mechanizm partycypacji. Zasadnie można stwierdzić, że mamy tutaj do czynienia z pojawieniem się logiki ponadjednostkowej oraz ponadlokalnej (Poniedziałek, 2011, s. 36). Partycypowanie w procesach kształtowania regionu wymuszane jest przez stosowanie przez organizacje regio- 
nalne sformalizowanych kodeksów (np. regulacji prawnych, strategii) oraz poprzez wpływanie na formowanie się regionalnej mitografii, a w dalszej konsekwencji także regionalnej tożsamości rozpowszechnionej w świadomości mieszkańców regionu. Dzieje się tak albowiem organizacje regionalne działają również w sferze dyskursywnej.

Region jest „jednocześnie produktem i podstawą działań społecznych oraz odzwierciedla asymetryczne relacje władzy i geometrię władzy w tym sensie, że niektórzy aktorzy w większym stopniu uczestniczą w wytwarzaniu miejsc i skal geograficznych, podczas gdy większość konsumuje i reprodukuje je tylko w codziennych praktykach i działaniach. Z oczywistych względów politycy, biznesmeni, urzędnicy, nauczyciele, ludzie mediów i kultury oraz naukowcy zajmują uprzywilejowaną pozycję w procesie definiowania znaczeń związanych z przestrzenią” (Bukowski, 2011, s. 52). Działając z pozycji uprzywilejowanych, w porządku dyskursu regionalnego wskazane typy aktorów regionalnych kształtują również działania społeczne, wpływają na rozpowszechnione w regionie typy oczekiwań i formy oraz treści tożsamości odnoszących się do regionu, wikłając w ten sposób w procesy kształtowania regionu również zwykłych jego mieszkańców.

\section{FAZA PEŁNEJ INSTYTUCJONALIZACJI REGIONU}

Fazę czwartą Passi nazywa pełną instytucjonalizacją. Na tym etapie procesy kształtowania się regionu nie ustają, ale można stwierdzić, że region zostaje w wyniku charakteryzowanego tu procesu powołany do życia. Inaczej mówiąc, mamy do czynienia na tym etapie z pełną jego instytucjonalizacją. Wzajemnie na siebie wpływające wymiary instytucjonalizowania się regionu: terytorialny, symboliczny i instytucjonalny zaczynają formować silną tożsamość regionalną, częstokroć polityzowaną przez organizacje regionalne w celu reprodukowania regionu w wymiarze dyskursu oraz działań społecznych. Dyskursywna działalność organizacji regionalnych wraz z silnymi tożsamościami regionalnymi prowadzą do tworzenia się swoistej regionalnej ideologii, w której region to względnie samodzielna jednostka gospodarcza, polityczna czy kulturowa. Wówczas to wokół ideologii regionalnej może narodzić się wykorzystujący do swych działań spolityzowaną tożsamości regionalną regionalizm, jako ideologia i typ formalnych lub nieformalnych działań społecznych nakierowanych na uzyskanie przez region jakiegoś stopnia autonomii. Paasi zaznacza, że formujące się wówczas organizacje i ruchy regionalistyczne nie budują całkowicie nowych tożsamości regionalnych, specyficznie strukturyzują treści zawarte w już istniejących, wykorzystując te zmienione 
tożsamości w celu budowania własnej ideologii, legitymizując w ten sposób swoją działalność (2009, s. 33).

W skrajnych wypadkach w tej fazie możemy mieć do czynienia z dążeniami autonomizacyjnymi, a nawet separatystycznymi. Swoistym modus operandi ruchów regionalistycznych lub separatystycznych jest budowanie ideologii regionalistycznych i intensywna polityzacja tożsamości regionalnych. Pełna instytucjonalizacja umożliwia rozwinięcie udanego marketingu terytorialnego, jak również w przypadkach skrajnych, rozpoczęcie walki ideologicznej o władzę i suwerenność wobec państwowych struktur. Ten proces uzależniony jest w dużej mierze od kontroli nad tworzeniem dyskursów i praktyk w ramach instytucji aparatu administracyjnego, masowych mediów, instytucji edukacyjnych, religijnych czy zawodowych. Za Anną Gąsior-Niemiec można stwierdzić, że efektem tego procesu jest „legitymizacja nowego status quo; produkcja i dystrybucja pozycji, kapitału, ról, przywilejów, tożsamości i norm” (Gąsior-Niemiec, 2004, s. 26-27).

Region wyposażony w treści i instytucje w trzech wcześniejszych fazach wchodzi w stadium, w którym nie poprzestaje na wchodzeniu w relacje ze swoim otoczeniem wewnątrzpaństwowym (np. innymi regionami wewnątrz państwa, którego jest częścią, lub z jego centrum). Jako pewna zazębiająca się sieć relacji symbolicznych, dyskursywnych i instytucjonalnych stale produkowanych i reprodukowanych w odniesieniu do jakiegoś terytorium i zbiorowości, włącza się w ponadregionalne a nawet globalne sieci i przepływy gospodarcze, polityczne i kulturowe (Fitjar, 2009, s. 20). To włączanie często odbywa się bez pośrednictwa centrum państwa, którego region jest elementem.

Analiza teorii instytucjonalizacji regionu pozwala stwierdzić, że trzy pierwsze fazy procesu dotyczyły tożsamości regionalnej in statu nascendi. W fazie czwartej mamy do czynienia z uformowaną, silną, choć podlegającą zmianom i przekształceniom, tożsamością społeczną jednostek odnoszącą się do regionu (Schrijver, 2006, s. 62). „Owe tożsamości zaś nie są czymś stałym i niezmiennym, lecz tworzą tymczasowe konstrukcje dzięki nieustannemu odnoszeniu się i konfrontowaniu z innymi konstrukcjami” (Bukowski, 2011, s. 189). Do tych konstrukcji należą tworzone przez organizacje regionalne obrazy i wyobrażenia regionu mające komunikować jego istnienie oraz odmienność i specyfikę. Dochodzi wówczas do intensywnej mobilizacji zasobów symbolicznych w celu wypracowania i wypromowania swoistej marki regionalnej, symboli, wyobrażeń i uproszczonych skojarzeń mających budować regionalną dystynkcję, symbolizowaną przez regionalną markę. W tym momencie pojawia się konieczność rozróżnienia tożsamości regionalnej i tożsamości regionu, dwóch konfrontujących się ze sobą konstruktów będących 
efektem procesu instytucjonalizowania się regionu (Keating, 2003, s. 86). Paasi proponuje rozróżnienie analityczne tych dwóch pozornie identycznych kategorii. Przypominając dialektykę kształtowania się regionalnych identyfikacji, polegającą na odgórnym i oddolnym jej formowaniu, podkreśla, że pomimo licznych związków są to zjawiska, które należy potraktować odrębnie.

\section{TOŻSAMOŚĆ REGIONALNA A TOŻSAMOŚĆ REGIONU}

Tożsamość regionalna mieszkańców będzie składnikiem ich świadomości społecznej, to złożony proces identyfikowania się jednostek z grupą traktowaną jako własna, inna i odrębna od grup i zbiorowości regionalnych zamieszkujących inne obszary. To typ tożsamości uformowany przez swoiste regionalne mitografie. Passi podkreśla, że tożsamość regionalna „odnosi się do wielopłaszczyznowego procesu identyfikowania się ludzi z tymi praktykami, dyskursami i symbolizacjami, wyrażającymi się jako struktura oczekiwań, która instytucjonalizuje się jako element procesu nazywanego regionem” (Paasi, 2003, s. 478). Fiński badacz podkreśla, że należy odejść od definiowania tożsamości regionalnych jako zamkniętych w ograniczonej przestrzeni całości kulturowych, albowiem w świecie złożonych i wielopłaszczyznowych interakcji takowe tożsamości po prostu nie istnieją. Powinny być one ujmowane „w kategoriach relacyjnych jako złożone i płynne, ponieważ wielokrotne tożsamości są coraz bardziej związane z mobilnością, sieciami i interakcjami funkcjonującymi w miękkich przestrzeniach, które występując przekraczają rozmyte granice” (Paasi, 2013, s. 1208).

Tożsamość regionu to kategoria odnosząca się do tych jego cech przestrzeni fizycznej, wyróżników kulturowych lub charakterystyk społecznych (rzeczywistych bądź kreowanych), które używane są w regionalnych praktykach dyskursywnych, oraz „,klasyfikacjach naukowych, politycznych, w aktywności kulturalnej, w regionalnym marketingu czy zarządzaniu, a także politycznej lub religijnej regionalizacji, dokonywanych w celu odróżnienia regionu od innych. Te klasyfikacje zawsze są aktami władzy przedsiębranej w celu delimitacji, nazwania i symbolizowania przestrzeni i grup społecznych” (Paasi, 2013, s. 1208). W wymiarze analitycznym tożsamość regionalna to oddolny wymiar instytucjonalizowania się regionu (bottom up), zaś jej depozytariuszami są jego mieszkańcy. Tożsamość regionu natomiast wytwarzana jest niejako odgórnie (top down) przez aktorów społecznych skupiających swą aktywność w organizacjach regionalnych mających zdolność operowania w sferze symbolicznej i komunikacyjnej w taki sposób, że są w stanie nadawać kształt regionalnemu dyskursowi. 
Rozróżnienie dokonane przez Paasiego wydaje się sensowne, albowiem w czasach masowej produkcji regionów umożliwia prześledzenie procesu intensywnego wytwarzania tożsamości regionu jako produktu czy marki, „która w większym stopniu może przełożyć się na rzeczywiste postawy i zachowania jego mieszkańców (habitus) niż na poziom ich afektywnej lub ideologicznej identyfikacji $\mathrm{z}$ danym terytorium. $\mathrm{Z}$ drugiej strony umożliwia także zrozumienie tego, iż w dobie intensywnej migracji (oraz zmian terytorialno-administracyjnych) pamięć zbiorowa przechowuje niekiedy coś, co można by określić właśnie mianem tożsamości regionu - obrazy i stereotypy, które następnie w sposób automatyczny przypisywane są zbiorowości (autochtonicznej lub napływowej, homogenicznej kulturowo bądź mocno zróżnicowanej) ten region zamieszkującej” (Gąsior-Niemiec, 2004, s. 29). Tożsamość regionu jest wykorzystywana do tworzenie regionalnej dystynkcji. Używany w praktyce zespół symboli ma kształtować wewnątrz regionu jego spójny, zgodny z intencjami tworzących go autorów system wyobrażeń. Na zewnątrz te wyobrażenia mają funkcjonować jako regionalna marka, która nie tylko buduje obraz regionu jako jakości unikalnej i specyficznej, ale ma przyczyniać się do tworzenia wizerunku regionu jako miejsca atrakcyjnego dla obecnych i przyszłych jego mieszkańców, dla firm, które już zainwestowały w regionie, przyczyniając się do jego rozwoju, lub tych, które mogą to uczynić.

Istotne jest również wykazanie wielorakich związków pomiędzy tożsamością regionalną a tożsamością regionu. Te dwie kategorie w praktyce społecznej stale się ze sobą ścierają i konfrontują, trwa nieustanna rywalizacja o to, który z typów tożsamości będzie miał większy wpływ na formowanie się regionu. Owa walka jest immanentną cechą procesów regionotwórczych, wiąże się to z wpisanymi w ten proces praktykami przemocy symbolicznej. Twórca charakteryzowanej tu teorii, odwołując się do twórczości Bourdieu, wskazuje, że konflikt o kształt i treści zawarte w tożsamościach odnoszonych do regionu „to szczególny przypadek walki o możliwość narzucenia klasyfikacji, walka o monopol władzy nad tym, co ludzie widzą i w co wierzą, co wiedzą rozpoznając jako prawdziwe, tak by narzucić prawomocną definicję podziałów świata społecznego w celu tworzenia i niszczenia ludzkich zbiorowości” (Bourdieu, 1991, s. 221). Walka toczy się pomiędzy depozytariuszami tożsamości regionalnej a producentami i dystrybutorami tych treści, które konstytuują tożsamość regionu. Czyli pomiędzy mieszkańcami regionu a organizacjami regionalnymi, przy czym znacznie większe możliwości formowania treści tożsamościowych mają ci, którzy mogą manipulować regionalnym dyskursem, czyli aktorzy skupieni w organizacjach regionalnych. Do walki dochodzi również pomiędzy poszczególnymi organizacjami wewnątrz regionu, a także pomiędzy nimi a otoczeniem zewnętrznym. O to, który z konstruktów 
odnoszony do regionu i przez kogo uformowany, stanie się obowiązujący, „trwa nieustanna walka, a jej efekt jest zawsze tymczasowy” (Bukowski, 2011, s. 54). Zarówno tożsamości regionalne, jak i tożsamości regionów nie są nigdy ukończone ani trwałe, są konstruowane przez ludzi i organizacje przy użyciu różnych sposobów, powstają poprzez formowanie się w większe całości różnych treści, konfrontowane są z różnym typem doświadczeń, praktyk i dyskursów (Paasi, 2000, s. 97). W ten sposób wyłania się i reprodukowany jest jako efekt konfrontacji wyobrażeń różnych aktorów społecznych, jednostkowych i zbiorowych, a także instytucjonalnych, zlokalizowanych na jakimś obszarze, instytucjonalizujący się region.

\section{INSTYTUCJONALIZACJA REGIONU - UZUPEENIENIE KONCEPCJI}

Charakteryzowana tu teoria należy do najciekawszych prób opisania tego trudno uchwytnego bytu, jakim jest region. Zdaje się, że największą wartością tej koncepcji jest ukazanie wielorako złożonych i dynamicznych procesów społecznego wytwarzania regionów. To podejście stanowi „dojrzałą syntezę różnych stanowisk i podejść w ramach instytucjonalnego konstruktywizmu” (Bukowski, 2011, s. 54). Wypracowana na gruncie geografii humanistycznej koncepcja doskonale nadaje się do socjologicznych badań nad regionami, przełamuje bowiem dominację podejść, w których region z reguły charakteryzowany jest przez jedną, względnie kilka statycznych właściwości. Taki typ opisywania regionu okazuje się niedoskonały, ,albowiem w zmiennym czasie historycznym jedne właściwości tracą na znaczeniu, podczas gdy inne odwrotnie, zyskują” (Kubiak, 2007, s. 90). To, co istotne u Paasiego, to próba ukazania związków pomiędzy elementami budującymi region, czyli opis regionu w kategoriach relacyjnych (Rykiel, 2011, s. 95-98).

Koncepcja Paasiego nie pozwala na ujmowanie regionów w kategoriach zwartych i zamkniętych na ograniczonej przestrzeni jednostek terytorialnych, społecznych, kulturowych, politycznych i gospodarczych. To odejście od ciągle, w szczególności w polskich naukach społecznych i humanistycznych, rozpowszechnionej perspektywy, w której region to zlokalizowana w przestrzeni strukturalna jedność, gdzie zbiorowość posiadała czytelną i wyraźną tożsamość i wyraźnie określone, najczęściej ukształtowane historycznie cechy charakterystyczne. W przypadku teorii instytucjonalizacji, nawiązującej do społecznego konstruktywizmu, region to konstrukcja otwarta, niemająca żadnych stałych atrybutów przestrzennych, społecznych czy kulturowych. To, co jest regionem, to efekt działań, konfrontacji 
i ustalania przez różne typy regionalnych aktorów społecznych w regionalnych grach obowiązujących typów wyobrażeń regionu. Jednostki, grupy społeczne i instytucje „walczą o to, by ich interpretacja stała się obowiązującą, a instytucje, które przynoszą im największe korzyści - dominującymi w regionie. Często te zwycięskie narracje traktuje się z zewnątrz jako właściwą tożsamość i charakterystykę regionu, tymczasem to tylko przejściowe i częściowe rozstrzygnięcia. Inne grupy czy środowiska mogą właśnie przygotowywać się do zdetronizowania zwycięskiej narracji bądź zakwestionowania dominujących interesów” (Bukowski, 2011, s. 54-55). Region jest nie tylko przestrzennie ulokowanym typem zbiorowości społecznej spajanej wspólną tożsamością regionalną, jest przede wszystkim polem, na którym rozgrywa się instytucjonalna gra o to, czyje konstrukty w postaci dyskursywnie formowanych obrazów regionu staną się obowiązujące. Z reguły w tej symbolicznej walce zwyciężają najsilniejsze, obdarzone władzą polityczną, ekonomiczną i symboliczną organizacje regionalne (np. władze i powiązane z nimi instytucje, firmy, grupy interesów). Wydaje się jednak, że tego rodzaju radykalny konstruktywizm w odniesieniu do procesów formowania się regionu nie oddaje w pełni jego charakteru.

Po pierwsze, należy podważyć apriorycznie przyjmowany przez Paasiego postulat względniej stabilności otoczenia zewnętrznego regionu oraz całkowitą niemalże niemożność wpływania zwykłych mieszkańców na procesy regionotwórcze. To przyjęcie założenia, że proces instytucjonalizowania się regionu zostanie zainicjowany być może wówczas, gdy w regionie istnieją silne organizacje skupiające wyposażone w wysoki poziom kapitału kulturowego elity regionalne. W grze o wytworzenie regionu uczestniczą tylko tego rodzaju grupy i instytucje, natomiast zwykli mieszkańcy sprowadzeni są do roli biernych odbiorców treści dyskursywnych tworzonych i narzucanych odgórnie (Poniedziałek, 2011, s. 36-37).

Paasi zakłada, że fazy procesu „niekoniecznie następują jedna po drugiej w opisanym porządku, przeciwnie są wzajemnie powiązane” (Schrijver, 2006, s. 62). Niemniej jednak po lekturze jego tekstów można odnieść wrażenie, że fiński badacz regionów de facto skłania się ku poglądowi mówiącemu, że opisane przez niego fazy zachodzą w porządku chronologicznym, a każda następna jest logiczną konsekwencją poprzedniej. Dodatkowo w prezentowanej tu teorii zakłada się, że regiony są wytwarzanymi instytucjonalnie dyskursywnymi konstrukcjami, kruchymi, złożonymi, zmiennymi kontekstualnie. Jeżeli powyższy sąd jest prawdziwy, to, co „powoduje, że wiele instytucji regionalnych zachowuje tak zadziwiającą trwałość, ciągłość spójność i niepodatność na zmiany w okresach setek lat. [...] Co sprawia, że pomimo otwartości i dynamiki społecznych procesów konstruowania rzeczywistości, zamiast nieskończonego różnicowania 
się form instytucjonalnych, zachodzi tak wiele podobieństw w funkcjonowaniu instytucji” (Bukowski, 2011, s. 55).

Wątpliwości budzi założenie o względnej stabilności otoczenia regionu, ulokowaniu źródeł procesów regionotwórczych tylko w ramach regionalnych instytucji, faktyczna zgoda na to, że fazy instytucjonalizacji zachodzą w porządku chronologicznym i logicznym. Nie można również zgodzić się ze stwierdzeniami, że w procesach regionotwórczych elity skupione w formalnych instytucjach ex nihilo wytwarzają treści symbolicznie, zaś ich skład i możliwości uznania za prawomocne nie zależą od treści kulturowych już funkcjonujących w regionie, niezależnie od gier regionalnych podejmowanych przez elity. Treści, które z dawien dawna formowały tożsamości regionalne, regionalne imaginarium i regionalną kulturę. W celu przezwyciężenia wskazanych wcześniej słabości zaproponuję własną modyfikację tej cennej i ważnej dla socjologii regionu koncepcji.

Region jest niewątpliwie społecznym konstruktem, który tworzy się i przejawia w procesach instytucjonalizowania interakcji społecznych. Jak stwierdzają Keith Archer i Lisa Young, tworzą one powtarzalną w czasie sieć wyobrażeń symbolicznych, wzorców zachowań i praktyk instytucjonalnych odnoszonych do jakiegoś terytorium (Archer, Young, 2002, s. 24). Regiony tworzone są „przez dyskursy, które komunikują, czym jest region. Tworzą się z różnych powodów i przyczyn, włączając w to polityczne, kulturowe i ekonomiczne” (Fitjar, 2013, s. 71). Nie ma powodu, aby rezygnować z zaproponowanej przez Paasiego koncepcji instytucjonalizowania się regionu poprzez wyłaniania się jego kształtu terytorialnego, symbolicznego i instytucjonalnego oraz pojawienia się regionu jako efektu procesu wzajemnego wpływania na siebie wspomnianych wymiarów opisywanego tu procesu. Należy podkreślić jednak, że nie są to zachodzące jedna po drugiej fazy, ale raz silniej, raz słabiej ujawniające swą obecność przejawy tego samego procesu. Z reguły zachodzą jednocześnie, bywa, że któryś z wymiarów inicjuje kolejne, bywa również, że przez jakiś ograniczony czas dominuje nad innymi. W taki zazębiający się sposób zachodzi właśnie proces instytucjonalizowania się regionów.

Jednostki, grupy społeczne, formalne i nieformalne organizacje we wzajemnych relacjach tworzą regionalne zasoby symboliczne, przekształcane w społeczne instytucje. Dochodzi do tworzenie więzi społecznych, ich utrzymywania lub znoszenia i zastępowania starych nowymi, więzi, które tworząc sieć, uczestniczą w budowaniu i podtrzymywaniu istnienia instytucjonalizującego się regionu. Region jest więc społecznym, kulturowo osadzonym procesem konstruowania i ustawicznego rekonstruowania zbiorowości społecznej, regionalnej symboliki i instytucji odnoszonych do konkretnego, ograniczonego terytorium. Instytu- 
cje w tym procesie pełnią rolę „kulturowego instrumentarium. Z jednej strony przyjmują postać formalnych przepisów i praw, nieformalnych reguł, kodów obyczajowych, systemów klasyfikacji, zbiorowych wyobrażeń, idei oraz oczekiwań, z drugiej - rutyn, nawyków, przyzwyczajeń, skryptów zachowań, schematów poznawczych i oczekiwań jednostkowych, ściśle powiązanych z regułami życia zbiorowego" (Bukowski, 2011, s. 9).

Za Markiem S. Szczepańskim stwierdzam, że region należy ujmować jako dynamiczne zjawisko, tworzące w procesach instytucjonalizacji jednostkę społeczno-przestrzenną, „w której wyrażają się długotrwałe procesy historyczne i trendy sekularne” (Szczepański, 1991, s. 367). Takie podejście unieważnia ahistoryzm teorii instytucjonalizacji regionu, niemniej jednak nie postuluje powrotu do ujmowania regionu jako niepoddającego się zmianom, symbolicznym i instytucjonalnym rekonstrukcjom, osadzonego przestrzennie i sięgającego głęboko w przeszłość zbiornika regionalnych wyróżników kulturowych. Region jest konstrukcją dynamiczną, relatywnie otwartą i poddającą się zmianom, niemniej jednak na owe zmiany i zabiegi konstrukcyjne w dużej mierze wpływają przeszłe próby i efekty instytucjonalizowania się regionu w jakiejś przestrzeni. Proces ów zależny jest od zobiektywizowanych w przeszłości wyobrażeń o terytorium regionu, jego symbolicznych i instytucjonalnych wzorców. Z przestrzenią regionu wiązane są wyobrażenia, symbole i instytucje, przez to, że tworzą wrażenie istnienia regionu jako całości społeczno-kulturowej legitymizowanej odrębnymi dziejami (Samsonowicz, 1998). Na instytucjonalizowanie się regionów wpływa przeszłość, warunki społeczno-kulturowe i polityczno-gospodarcze, które stanowią punkt wyjścia dla współczesnych procesów kształtowania się regionów (Misiak, 2005, s. 88). Procesy instytucjonalizowania się regionu oparte są na rzeczywistej, wyobrażonej lub narzucanej instytucjonalnie wspólnocie „[...] losów historycznych, które odróżniają go od pozostałej części społeczeństwa narodowego lub państwowego” (Starosta, 1999, s. 43). Region instytucjonalizuje się poprzez przekształcanie ram terytorialnych, zasobów symbolicznych i wzorów instytucjonalnych odziedziczonych z przeszłości lub tworzenie nowych (często z połączenia elementów odziedziczonych i wytworzonych). Wzorce odziedziczone bądź wytworzone adaptowane są zarówno do środowiska i specyfiki wewnątrzregionalnej, jak i do uwarunkowań wobec regionu zewnętrznych.

Otoczeniem zewnętrznym regionu są inne regiony, często wchodzące z instytucjonalizującym się regionem w wielorakie typy oddziaływań o charakterze kooperacji w realizacji jakichś wspólnych celów czy konkurencji o zasoby, terytorium, symbole lub o dominację w jakimś większym układzie (np. państwie). W skład otoczenia zewnętrznego wchodzą również inne byty społeczno-przestrzenne sąsiadu- 
jące z regionem (np. leżące w obrębie granic innych regionów społeczności lokalne tworzące strefę regionalnych pograniczy), jak również państwa, których region jest częścią składową, państwa inne oraz zjawiska z poziomu międzynarodowego (np. zjawiska globalne, instytucje transnarodowe czy bloki i ugrupowania państw). Procesy instytucjonalizacji regionu, polegające na społecznym i kulturowym jego konstruowaniu, toczą się również we wskazanych skalach ponadregionalnych. W ten sposób uwypuklone zostają granice regionu, które przybierają postać rozgraniczeń o charakterze formalnym (wyznaczane administracyjnie terytorium regionu) czy kulturowym (zasięg występowania specyficznych dla regionu cech kulturowych, np. zwyczaje, tradycje, dialekty itp.). Paweł Starosta zasadnie podkreśla, że „region jest obszarem, którego społeczno-kulturowe granice nie muszą pokrywać się zwykle z granicami polityczno-administracyjnymi” (Starosta, 1999, s. 43). Specyfika kulturowa regionu tworzy płynną porowatą i niestałą granice, często trudno uchwytną na drodze badań empirycznych. Rację ma Klaus Roth, stwierdzając, że „większość regionów historycznych czy tradycyjnych nie ma wyraźnych granic” (Roth, 2007, s. 22).

Zbyszko Chojnicki i Teresa Czyż zasadnie wskazują, że relacyjność regionu ma również charakter wewnętrzny. W tym przypadku odnosi się do relacji i oddziaływań społecznych, kulturowych i gospodarczych, a niejednokrotnie i politycznych pomiędzy strukturami o charakterze subregionalnym i lokalnym, tworzącymi region od wewnątrz (Chojnicki, Czyż, 1993, s. 22). Powiązania wewnętrzne skupiają się w centrum regionu, który jak stwierdza Robert E. Dickinson, tworzy jego rdzeń. To tam zbiegają się regionalne powiązania polityczne, które z reguły znajdują przestrzenną lokalizację w postaci regionalnej stolicy czy metropolii. Jednakże poza nimi „inne czynniki - historyczne, kulturowe czy gospodarcze, również ogrywają tu istotną rolę” (Dickinson, 2007, s. 198). Zasięg występowania tych powiązań zarysowuje granicę funkcjonalną regionu. Regiony stanowią ramy terytorialne dla występujących na jakimś obszarze specyficznych cech kulturowych, jednakże „rzadko koncentrują się one w granicach odpowiadających regionom rozpatrywanym w innych sensach funkcjonalnych” (Keating, 1997, s. 384). Realistyczne podejście do faktycznie istniejących granic, prezentowane tu jako jedna z korekt teorii instytucjonalizacji regionu, stoi w sprzeczności z poglądami Paasiego, dla którego granice regionu są tylko symbolizacjami aktów władzy, ramami wyobrażeń, które narzucane przez elity regionalne mają stać się prawomocne (Paasi, 2001, s. 16). Pomimo realnie i symbolicznie funkcjonujących granic regionu nie stanowią one nieprzepuszczalnej bariery, co powoduje, jak powiada Michel Keating, że współczesny region jest „miejscem oddziaływania aktorów z poziomu narodowego, lokalnego, regionalnego i obecnie ponadpaństwowego” (Keating, 2004, s. 17). 
Region jest takim typem zjawiska społeczno-przestrzennego, w którym różnego rodzaju aktorzy społeczni, wchodząc w interakcje, reprodukują lub modyfikują zastane zasoby symboliczne i instytucje społeczne, adaptując je do aktualnych uwarunkowań. Jest to swoista gra toczona pomiędzy jednostkami, grupami społecznymi i organizacjami funkcjonującymi w regionie, owa gra sprawia, że region to zawsze terytorium, na którym odbywa się pomiędzy nimi swoista rywalizacja. To rywalizacja o sprawowanie regionalnego władztwa politycznego, gospodarczego, ale przede wszystkim symbolicznego. Podkreślić należy, że wspominana gra regionalna nie zawsze, jak zdaje się przekonywać Paasi, ma charakter antagonistyczny. Niekiedy pomiędzy grupami społecznymi mieszkającym w regionie a regionalnymi organizacjami dochodzi do konsensusu, wówczas instytucjonalizujący się region jest efektem konstruktywnej kooperacji, to efekt przenikania się instytucji i kultury w regionie oraz wzajemnego wpływu różnych typów aktorów regionalnych na siebie nawzajem.

Aktorzy regionalni różnego typu dokonują swoistej mediacji pomiędzy własnym dziedzictwem kulturowym a otoczeniem instytucjonalnym w ograniczonej zewnętrznie i wewnętrznie przestrzeni społeczno-kulturowej. W procesie instytucjonalizowania się regionu biorą udział wszyscy aktywni, podejmujący grę aktorzy regionalni, grupy mieszkańców i regionalne organizacje. Przebieg tego rodzaju mediacji wyznacza kontekst zewnętrzny wobec regionu (wpływ sił globalnych, ingerencje ze strony państwa itp.) i wewnętrzny, ramy wyznaczane przez formalne uregulowania prawne funkcjonujące w regionie, sieć zależności gospodarczych i politycznych, specyfikę zbiorowości regionalnej. Mediację kanalizuje przeszłość, a ściślej rzecz ujmując, wytworzone w przeszłości historyczne zasoby kulturowe. W wyniku mediacji wypracowana zostaje nowa jakość w postaci zaadaptowanych do konkretnych czasów i uwarunkowań regionalnych zasobów symbolicznych i instytucjonalnych (Tatur, 2004, s. 41). W ten sposób, odwołując się do koncepcji Melanie Tatur, sięgającej do teorii strukturacji Anthony’ego Giddensa, teoria instytucjonalizacji regionu uzupełniona zostaje o twierdzenie o podmiotowym charakterze działań wszystkich typów aktorów społecznych w regionie. Wprowadzenie elementów podmiotowości do koncepcji instytucjonalizowania się regionu uzupełnia jego obraz, albowiem w konstruowaniu regionu biorą udział wszyscy aktorzy regionalni, nie tylko zaś regionalne elity skupione w posiadających władzę polityczną, ekonomiczną i często symboliczną organizacjach regionalnych. Region konstytuowany jest nie tylko przez to, co Paasi nazywa marką regionu, ale również przez tożsamość regionalną jego mieszkańców, jest to, jak wskazuje Rune D. Fitjar, warunek sine qua non istnienia regionu (Fitjar, 2005, s. 59). Zarówno treść i formy marki regionu, jak i tożsamość regionalna mieszkańców mogą ulegać 
zmianom w zależności od zmieniających się uwarunkowań społeczno-kulturowych i polityczno-gospodarczych (Fitjar, 2013, s. 71).

Region wytwarzany jest w dialektyce tego, co podmiotowe i strukturalnie ograniczające. Procesy regionotwórcze odzwierciedlają się w instytucjonalizacji, a jest „to krystalizujący się, utrwalający i kumulujący efekt działań ludzkich, który - gdy zostaje utrwalony przez odpowiednią liczbę ludzi na określonej przestrzeni - staje się ramą i punktem odniesienia dla kolejnych działań” (Bukowski, 2011, s. 10). Regiony są konstruowane materialnie, symbolicznie i instytucjonalnie przez wszystkich aktorów regionalnych, rezultaty tych praktyk wpływają na inne, wzajemnie się inspirując i modyfikując. Zgodnie z założeniami realizmu ontologicznego to aktorzy społeczni, jednostkowi lub zbiorowi, są motorem działań społecznych, nie zaś tworzone przez nich bezosobowe struktury, strategie i dyskursy. One stają się narzędziami, które służą aktorom społecznym w działaniach społecznych mających na celu przekształcanie rzeczywistości społecznej. Region to efekt podmiotowych działań podejmowanych przez regionalnych aktorów w ramach instytucjonalnych i strukturalnych ograniczeń oraz historycznych procesów społeczno-kulturowych czy gospodarczych i politycznych, odniesionych do jego terytorium. W ten sposób w teorię instytucjonalizacji wplecione zostały elementy historycznie zorientowanej socjologicznej koncepcji podmiotowego widzenia świata społecznego.

\section{ZAKOŃCZENIE}

W polskiej socjologii regionu dominuje podejście humanistyczne, które w regionie każe widzieć zbiorowość regionalną osadzoną w ograniczonej przestrzeni, spajaną tożsamością regionalną i przywiązaniem do ojczyzny prywatnej. Odnosi się również wrażenie, że znaczna część definicji regionu to lista jego składników strukturalnych, które występują, ale nie wchodzą ze sobą w relacje. W zadziwiający, znany tylko autorom tego typu statycznych definicji sposób, owo współwystępowanie daje w efekcie rezultat w postaci pojawienia się regionu. Prezentowana tu teoria instytucjonalizacji regionu autorstwa Ansii Paasiego ukazuje, w jaki faktyczny sposób możliwe jest pojawienie się i funkcjonowanie regionu. Region to dynamiczny byt społeczno-przestrzenny, wyłaniający się w procesie wielofazowej instytucjonalizacji. To swego rodzaju dyskursywna gra podejmowana przez elity regionalne działające w formalnych instytucjach po to, aby wytworzyć tożsamość regionu, kształtować tożsamość regionalną aktorów społecznych oraz odbiór regionu na zewnątrz po to, by zdobyć symboliczną i faktyczną władzę w regionie. Teoria instytucjonalizacji wymagała kilku korekt, mianowicie stwierdzenia, że 
w procesie instytucjonalizacji biorą udział nie tylko regionalne elity, ale również jednostki i grupy jego zwykłych mieszkańców. Co więcej, instytucjonalizacja uzależniona jest od wytworzonego w przeszłości kontekstu symbolicznego i instytucjonalnego. Konstruktywny instytucjonalizm został uzupełniony w ten sposób przez twierdzenia o podmiotowym charakterze działań ludzkich, które zależne są od kontekstu historycznego, specyficznego dla poszczególnych regionów.

\section{Literatura:}

Archer, K., Young, L. (2002). Regionalism and Party Politics in Canada. Oxford: Oxford University Press.

Anderson, B. (1997). Wspólnoty wyobrażone. Kraków: Znak.

Bourdieu, P. (1991). Language and Symbolic Power. Cambridge: Polity Press.

Bukowski, A. (2009). Władza, terytorium, Tożsamość. Społeczne konstruowanie regionu. W: A. Bukowski, M. Lubaś, J. Nowak (red.), Zarządzanie przestrzenią (s. 73-114). Kraków: UJ.

Bukowski, A. (2011). Region tradycyjny w unitarnym państwie w dobie globalizacji. Kraków: UJ.

Chądzyński, J., Nowakowska, A., Przygodzki, Z. (2007). Region i jego rozwój w warunkach globalizacji. Warszawa: CeDeWu.

Chojnicki, Z., Czyż, T. (1993). Region i regionalizacja w geografii. W: K. Handke (red.), Region, regionalizm - pojęcia i rzeczywistość (s. 13-36). Warszawa: SOW.

Chojnicki, Z. (1996). Region w ujęciu geograficzno-systemowym. W: T. Czyż (red.), Podstawy regionalizacji geograficznej (s. 7-43). Poznań: Bogucki Wydawnictwo Naukowe.

Dickinson, E.R. (2007). City, Region and Regionalism. Chaltenham: Edward Elgar.

Fitjar, D.R. (2005). Measuring Regionalism: Content Analysis and the Case of Rogalan in Norway. Regional and Federal Studies, 1 (15), s. 59-73.

Fitjar, D.R. (2009). The rise of regionalization: Causes of regional mobilization in Western Europe. London: Routledge.

Fitjar, D.R. (2013). Region-building in the Arctic Periphery: The Discursive Construction of a Petroleum Region. Geografiska Annaler: Series B, Human Geography, 1 (95), s. 71-88.

Gąsior-Niemiec, A. (2004). Pole, habitus i imago regionis: propozycja alternatywnego podejścia do analizy regionu. Studia Regionalne i Lokalne, 4 (18), s. 13-36.

Kania-Jasińska, A. (2006). Neoinstytucjonalizm. W: A. Jasińska-Kania, L.M. Nijakowski, J. Szacki, M. Ziółkowski (red.), Współczesne teorie socjologiczne (s. 549-552). Warszawa: Scholar.

Keating, M. (1997). The Invention of Regions: Political Restructuring and Territorial Government in Western Europe. Environment and Planning C, 15, s. 383-398.

Keating, M. (2003). The New Regionalism in Western Europe. Chaltenham: Edward Elgar. 
Keating, M. (2004). The Political Economy of Regionalism. W: M. Keating, J. Loughlin (red.), The Political Economy of Regionalism (s. 17-41). London: Routledge.

Kubiak, H. (2007). U progu ery postwestfalskiej. Kraków: Universitas.

Miazga, M. (2010). Z zagadnień socjologii regionu. Lublin: WSPA.

North, C.D. (1991). Institutions. The Journal of Economic Perspectives, 1 (5), s. 97-112.

Paasi, A. (1986). Institutialisation of regions: a theoretical framework for understanding the emergence of regions and the constitution regional identity. Fenni, 164, s. 105-146.

Paasi, A. (1991). Deconstructing regions: notes on the scales of spatial life. Environment and Plannig A, 23, s. 239-256.

Paasi, A. (1999). The Finnish-Russian border in a World of Deterrittorialisation. Nordregi: Sprinter.

Paasi, A. (2000). Territorial identities as social constructs. Hagar - International Social Science Review, 1 (2), s. 91-113.

Paasi, A. (2001). Europe as a Social Process and Discourse: Considerations of Place, Boundaries and Identity. European Urban and Regional Studies, 8 (1), s. 7-28.

Paasi, A. (2002). Place and Region: Regional Worlds and Words. Progress in Human Geography, 26, (6), s. 802-811.

Paasi, A. (2003). Region and Place: Regional Identity in Question. Progress in Human Geography, 4 (27), s. 475-485.

Paasi, A. (2009). The resurgence of the 'Region' and 'Regional Identity': theoretical perspectives and empirical observations on regional dynamics in Europe. Review of International Studies, 25, s. 121-146.

Paasi, A. (2013). Regional Planning and Mobilization of 'Regional Identity': From Bounded Spaces to Relational Complexity. Regional Studies, 47, s. 1206-1219.

Poniedziałek, J. (2010). Kształtowanie się regionu na Warmii i Mazurach. Studia Regionalne i Lokalne, 4 (42), s. 23-42.

Poniedziałek, J. (2011). Postmigracyjne tworzenie tożsamości regionalnej. Toruń: Adam Marszałek.

Roth, K. (2007). What's in a Region. Southeast European Regions. Etnologia Balcanica, 11, s. 17-42.

Rykiel, Z. (2011). Teorie regionu społecznego. W: M.S. Szczepański, A. Śliz, R. Geisler, B. Cymbrowski (red.), Socjologia regionu i społeczności lokalnych (s. 67-110). Opole: UO.

Samsonowicz, A. (1998). Analiza regionu. Warszawa: PWN.

Schijver, F. (2006). Regionalism after Regionalization: Spain, France and the United Kingdom. Amsterdam: Amsterdam University Press.

Starosta, P. (1999). Tożsamość regionalna w perspektywie socjologicznej. W: A. Matczak (red.), Badania nad tożsamością regionalną (s. 40-53). Łódz-Ciechanów: KODRTK.

Tatur, M. (2004). The Making of Regions in Post-Socialist Europe: the Impact of Culture, Economic Structure, and Institutions. Wiesbaden: VS Verlag fuer Sozialwissenshaften. Tomaszewski, K. (2007). Regiony w procesie integracji europejskiej. Warszawa: Wolters Kluwer Polska. 